\title{
Peningkatan minat dan prestasi belajar siswa melalui penerapan metode Kooperatif Question and Answer Simulation berbasis teknologi informasi (studi kasus: mata pelajaran Otomatisasi dan Tata Kelola Humas dan Keprotokolan di SMK Negeri 2 Magelang)
}

\author{
Priyani $^{1}$
}

1 Kompetensi Keahlian Otomatisasi dan Tata Kelola Perkantoran, SMK Negeri 2 Magelang, Jalan Jendral Ahmad Yani No. 135A, Magelang, Jawa Tengah priyani043@gmail.com

\begin{abstract}
Abstrak
Masalah rendahnya mutu sekolah sudah sangat sering dikeluhkan oleh masyarakat. Salah satu faktor yang ikut andil dalam penentuan mutu sekolah adalah proses pembelajaran yang sulit diikuti atau bahkan membosankan bagi siswa. Kondisi ini akan berpengaruh terhadap minat dan prestasi belajar siswa. Secara teori, metode Question and Answer Simulation akan membuat suasana belajar di kelas menjadi hidup dan siswa akan berlomba-lomba untuk memperoleh prestasi yang bagus. Penelitian ini bertujuan untuk membuktikan apakah penerapan metode Question and Answer Simulation dapat meningkatkan minat belajar, keaktifan siswa, dan prestasi belajar siswa. Penelitian ini berbentuk Penelitian Tindakan Kelas yang dilakukan secara kolaborasi oleh pengamat, siswa, dan guru teman sejawat pengampu mata pelajaran Kompetensi Keahlian Otomatisasi dan Tata Kelola Perkantoran di SMK Negeri 2 Magelang. Hasil penelitian menunjukkan bahwa terdapat peningkatan jumlah siswa yang berminat tinggi dan mempunyai aktifitas tinggi dalam pembelajaran. Peningkatkan prestasi belajar ditunjukkan oleh peningkatan jumlah siswa yang melampaui batas kriteria ketuntasan belajar, serta adanya persepsi dan kesan positif terhadap proses pembelajaran.
\end{abstract}

Kata Kunci CBSA, metode pembelajaran, penelitian tindakan kelas, metode QAS, prestasi belajar

\section{Pendahuluan}

Terdapat beberapa faktor yang ikut andil dalam penentuan mutu sekolah, diantaranya pembelajaran yang kurang bermutu bahkan cenderung sulit diikuti siswa secara menyeluruh, atau membosankan siswa. Hal ini tentu saja akan berpengaruh terhadap minat belajar anak dan pencapaian nilai hasil belajar. Untuk itu peranan guru dianggap sangat menentukan, guru yang bermutu akan menjadi idola siswa dalam pembelajaran, sehingga selalu ditunggutunggu kehadirannya di kelas. Penentuan mutu guru secara objektif akan dinilai oleh siswanya. Apabila seorang guru bisa menjadi idola siswanya dan bisa membawa ke arah pencapaian nilai yang tinggi di atas Kriteria Ketuntasan Minimal (KKM) dapat dikatakan sebagai guru bermutu. Pendidikan yang bermutu sangat memerlukan proses pengajaran dan pembelajaran yang berkualitas, yakni bisa dilakukan oleh guru yang bermutu dalam melakukan proses pembelajaran yang menyenangkan, mengasyikkan, dan mencerdaskan [1]. Peranan guru dalam dunia pendidikan yang terjun langsung ke lapangan adalah melaksanakan

\footnotetext{
(c) (i) () Priyani;

J12 alaka Yayasan Lentera Dua Indonesia
} 
pembelajaran untuk membawa anak didik menguasai kompetensi-kompetensi mata pelajaran. Untuk itu guru dituntut untuk selalu melakukan inovasi pembelajaran melalui berbagai metode pembelajaran yang dirasa tepat untuk peningkatan kompetensi siswa.

Di dalam proses pembelajaran, guru harus memiliki strategi, agar siswa dapat belajar secara efektif dan efisien, dan mengena pada tujuan yang diharapkan. Salah satu langkah untuk memiliki strategi itu, maka guru harus menguasai teknik-teknik penyajian, atau biasanya disebut dengan metode mengajar. Metode yang digunakan untuk memecahkan suatu masalah yang dihadapi oleh siswa atau menjawab suatu pertanyaan dari siswa akan berbeda dengan metode yang digunakan untuk tujuan agar siswa mampu berpikir dan mengemukakan pendapatnya di dalam menghadapi segala masalah. Dengan demikian sudah sewajarnya pula apabila setiap teknik mengajar hanya dapat digunakan di dalam situasi dan tujuan tertentu. Jika situasi dan tujuan berubah, maka cara mengajarnya juga harus berbeda. Hal ini menuntut seorang guru atau instruktur harus menguasai beberapa macam teknik penyajian dengan baik dan harus mampu memilih teknik yang efektif untuk mencapai suatu tujuan tersebut, tanpa terasa mengubah situasi pengajaran.

Salah satu metode yang dapat digunakan dalam pembelajaran adalah Question and Answer Simulation (QAS). Metode ini menyajikan materi pembelajaran melalui Cara Belajar Siswa Aktif (CBSA), dimana siswa mempelajari materi yang ditugaskan oleh guru secara kelompok dengan melakukan diskusi dengan anggota kelompoknya untuk saling memahami materi yang menjadi tugas kelompoknya. Setiap anggota kelompok diberi kebebasan untuk menanyakan materi yang kurang jelas atau sulit dipahami kepada guru, dan guru akan menjelaskan sampai siswa benar-benar paham. Hal ini berlaku untuk kelompok-kelompok yang lain. Setelah materi dipahami seluruhnya, siswa kemudian diberi tugas untuk membuat soal pilihan ganda dan essay yang nantinya akan digunakan untuk simulasi tanya jawab secara kelompok dengan pengacakan soal pada seluruh kelas. Metode QAS ini akan meningkatkan kreatifitas siswa dalam menyusun soal yang hots dan membuat siswa berfikir dan menganalisa soal sebelum memberikan jawaban. Dengan metode ini siswa juga akan mudah menguasai materi sambil membuat soal-soal untuk dijawab oleh kelompok lain. Nilai tertinggi pada saat melakukan simulasi tanya jawab menunjukkan kelompok yang baik dan kompak, sehingga setiap kelompok akan berusaha untuk mendapatkan nilai kelompok yang paling tinggi.

Metode QAS juga disebut metode kuis karena siswa akan menjawab soal-soal kuis yang diberikan oleh guru dari soal-soal siswa yang sudah diacak dengan batas waktu yang sudah diatur dan disepakati bersama antara siswa dan guru. Dengan metode ini siswa akan mempelajari seluruh materi pembelajaran pada setiap Kompetensi Dasar (KD) agar dapat menjawab pertanyaan kuis dengan benar. Dengan metode QAS suasana kelas juga menjadi hidup karena siswa akan berlomba-lomba untuk memperoleh nilai yang baik sesuai standar yang sudah ditentukan. Dengan metode QAS diharapkan siswa akan mencapai minat belajar yang tinggi yang memberikan dorongan atau motivasi untuk lebih giat dan semangat dalam mengikuti pembelajaran. Minat dan motivasi belajar siswa yang tinggi akan meningkatkan capaian nilai atau prestasi belajar. Berdasarkan latar belakang di atas, maka Penelitian Tindakan Kelas (PTK) ini mengevaluasi upaya peningkatan minat dan prestasi belajar pada mata pelajaran Otomatisasi dan Tata Kelola Humas dan Keprotokolan (OTKP) melalui metode QAS berbasis teknologi informasi (TI) pada siswa Kelas XII OTKP3 di SMK Negeri 2 Magelang pada Tahun Pelajaran 2019-2020. 


\section{Kerangka teori dan berfikir}

Terdapat empat konsep dasar yang terkait dengan PTK ini, yaitu pembelajaran kooperatif, metode pembelajaran QAS, prestasi belajar, dan TI. Pembelajaran kooperatif mengandung pengertian sebagai suatu sikap atau perilaku bersama dalam bekerja atau membantu diantara sesama struktur kerjasama yang teratur dalam kelompok, yang terdiri dari dua orang atau lebih dimana keberhasilan kerja sangat dipengaruhi oleh keterlibatan di antara anggota kelompok itu sendiri [2]. Pengertian yang mirip adalah pembelajaran kooperataif merujuk kepada berbagai macam metode pengajaran di mana para siswa bekerja dalam kelompok-kelompok kecil untuk saling membantu satu sama lainnya dalam mempelajari materi pelajaran [3]. Dari dua pengertian tersebut, dapat dipahami bahwa pembelajaran kooperatif adalah salah satu metode pembelajaran dimana siswa belajar dan bekerjasama dalam kelompok-kelompok kecil dan saling berkolaborasi dengan anggota empat sampai enam orang dengan struktur kelompok yang besifat heterogen. Setiap kelompok akan belajar bersama, berdiskusi untuk memecahkan masalah atau tugas yang diberikan guru secara kompak untuk sukses meraih prestasi belajar yang tinggi. Melalui interaksi belajar yang efektif siswa menjadi lebih termotivasi, percaya diri, mampu menggunakan strategi berfikir dan membangun hubungan interpersonal dengan baik.

Konsep kedua yang terkait PTK ini adalah metode pembelajaran QAS. QAS merupakan salah satu metode pembelajaran kuis berkelompok (quiz team) yaitu pembelajaran active learning dengan prinsip CBSA. QAS dapat menghidupkan suasana belajar, mengaktifkan siswa untuk bertanya maupun menjawab dan dapat meningkatkan tanggung jawab siswa terhadap tugas yang diberikan dengan cara yang menyenangkan dan tidak membosankan. Pada metode QAS siswa bersama-sama dengan tim atau kelompoknya mempelajari materi pembelajaran yang ditugaskan oleh guru sesuai dengan bagian masing-masing dan menanyakan kepada guru hal-hal yang belum atau kurang jelas. Guru memberikan penjelasan sesuai dengan pertanyaan siswa secara klasikal begitu seterusnya sampai seluruh siswa seluruh kelompok benar-benar jelas dengan materi pembelajaran yang menjadi tugasnya. Setelah semua materi jelas siswa diberi tugas untuk membuat soal pilihan ganda dan essay dengan jumlah tertentu untuk digunakan sebagai bahan simulasi tanya jawab antar kelompok.

Konsep penting berikutnya yang terkait PTK ini adalah terkait pengertian prestasi belajar. Prestasi belajar secara teori diartikan apabila sesuatu kegiatan dapat memuaskan suatu kebutuhan, maka ada kecenderungan besar untuk mengulanginya. Sumber penguat belajar dapat secara ekstrinsik (nilai, pengakuan, penghargaan) dan dapat secara ekstrinsik (kegairahan untuk menyelidiki, mengartikan situasi). Di samping itu siswa memerlukan dan harus menerima umpan balik secara langsung derajat sukses pelaksanaan tugas (nilai raport/nilai tes) [4]. Dalam definisi lain, prestasi belajar dapat juga disebut sebagai hasil belajar yang merupakan realisasi atau pemekaran dari kecakapan potensi atau kapasitas yang dimiliki oleh seseorang yang dapat dilihat dari perilaku daslam bentuk penguasaan pengetahuan, ketrampilan berfikir maupun ketrampilan motorik [5]. Sedangkan hasil belajar adalah kemampuan-kemampuan yang dimiliki siswa setelah menerima pengalaman belajarnya [6].

Untuk mencapai prestasi belajar siswa seperti yang diharapkan, maka perlu diperhatikan beberapa faktor yang mempengaruhi prestasi belajar yaitu, faktor internal, faktor yang timbul dalam diri individu itu sendiri dan faktor eksternal, faktor yang berasal dari luar siswa, diantaranya adalah keadaan keluarga, keadaan sekolah, dan lingkungan masyarakat [7]. Selain faktor-faktor di atas ada beberapa cara untuk meningkatkan prestasi belajar, salah satunya adalah gaya belajar dan cara belajar siswa. 
PTK ini dilaksanakan dengan memanfaatkan teknologi informasi. Istilah teknologi informasi telah didefinisikan oleh para pakar dalam banyak cara. Secara umum teknologi informasi ialah suatu studi perancangan, implementasi, pengembangan, dukungan atau manajemen sistem informasi berbasis komputer terutama pada aplikasi hardware (perangkat keras) dan software (perangkat lunak komputer).

Untuk mencapai hasil belajar yang optimal seperti yang dituangkan dalam rencana pembelajaran diperlukan kerangka pemikiran yang sesuai dengan landasan teori yang telah dikemukakan sebelumnya. Bertitik tolak pada rendahnya minat siswa pada mata pelajaran OTKP yang ditunjukkan dengan rendahnya keaktifan siswa dalam proses pembelajaran, sehingga prestasi atau capaian nilai hasil tes formatif tidak sesuai dengan harapan. Faktor rendahnya minat siswa pada mata pelajaran OTKP disinyalir disebabkan oleh:

1. pembelajaran yang tidak menarik,

2. embelajaran kurang melibatkan siswa secara aktif,

3. metode pembelajaran yang tidak bervariasi,

4. proses pembelajaran tidak membangkitkan minat siswa, dan

5. kurangnya dorongan atau penguatan dari guru.

Mengacu pada teori prestasi belajar [4], keberhasilan siswa dalam belajar dipengaruhi oleh banyak faktor, dan yang paling utama adalah proses belajar itu sendiri. Di dalam proses belajar terjadi interaksi siswa dengan sumber belajar. Faktor utama penentu keberhasilan proses pembelajaran di kelas adalah guru, karena guru merupakan pengelola seluruh komponen proses pembelajaran di kelas.

\section{Hipotesis Tindakan}

Berdasarkan kerangka teori dan kerangka berpikir pada bagian sebelumnya, maka hipotesis tindakan perbaikan pembelajaran melalui PTK ini adalah sebagai berikut:

1. penerapan metode kooperatif QAS dapat meningkatkan minat belajar siswa pada mata pelajaran,

2. penerapan metode kooperatif QAS dapat meningkatkan keaktifan siswa dalam proses pembelajaran,

3. penerapan metode kooperatif QAS dapat meningkatkan nilai hasil tes formatif, dan

4. ada persepsi dan kesan siswa yang signifikan terhadap penerapan metode kooperatif QAS.

\section{$4 \quad$ Metodologi}

Subjek kegiatan penelitian ini adalah Kelas XII OTKP3 SMK Negeri 2 Magelang. Karakteristik siswa pada subjek penelitian diantaranya adalah jumlah siswa 35 perempuan semua. Usia rata-rata siswa adalah 17-18 tahun, memiliki potensi dan kompetensi yang heterogen, keadaan ekonomi siswa sebagian besar tergolong ekonomi menengah ke bawah, pekerjaan orang tua siswa kebanyakan petani dan karyawan swasta, dan tempat tinggal cukup jauh dari sekolah.

SMK Negeri 2 Magelang merupakan tempat peneliti melaksanakan tugas mengajar dan mengampu mata pelajaran OTKP pada tiga kelas, yiatu Kelas XII OTKP1, OTKP2, dan OTKP3. Pada PTK ini Kelas XII OTKP3 digunakan sebagai sampel. Jam pembelajaran untuk mata pelajaran OTKP adalah 6 jam pembelajaran untuk setiap tatap muka setiap minggu, sehingga peneliti mempunyai waktu yang cukup untuk melaksanakan penelitian tanpa mengganggu kegiatan belajar mengajar mata pelajaran yang lain. 
Waktu pelaksanaan PTK meliputi dua siklus, siklus pertama dilaksanakan selama 3 kali pertemuan selama 3 minggu pada setiap hari Selasa, yaitu tanggal 21 dan 28 Januari dan 4 Februari 2019 dengan materi KD menerapkan penyusunan perjalanan dinas. Siklus kedua dilaksanakan selama 3 kali pertemuan selama 3 minggu pada setiap hari Selasa, yaitu tanggal 11, 18, dan 25 Februari 2019 dengan materi KD menerapkan penyimpanan dokumen administrasi humas dan keprotokolan.

PTK ini dilakukan dengan memanfaatkan perangkat TI yang digunakan untuk memproses data yaitu pengetikan soal (processing), menampilkan soal dalam bentuk slide (generating), menyimpan soal (storage), menyalin data (retrieval), dan mengirimkan (transmission). TI juga digunakan untuk mengukur kemampuan siswa dalam bentuk Computer Based Test (CBT) menggunakan SIM SMK Negeri 2 Magelang dengan alamat IP 203.30.236.63 dan password yang sudah ditentukan pada LMS CBT Moodle [8].

\section{Hasil dan pembahasan}

Dalam PTK ini ingin diketahui tentang seberapa besar minat belajar siswa terhadap mata pelajaran OTKP, seberapa besar keaktifan siswa dalam proses pembelajaran, seberapa besar nilai hasil ulangan siswa, dan bagimana persepsi dan kesan siswa tentang pelaksanaan pembelajaran dengan metode pembelajaran QAS. Data yang digunakan untuk analisis minat belajar siswa berupa skor pengamatan dan diinterpretasikan dalam analisis kualitatif berupa tinggi, sedang, dan rendah. Tes untuk prestasi belajar meliputi penilaian kognitif berupa data skor tertinggi, skor terendah, rerata, dan ketuntasan belajar siswa.

\subsection{Data minat belajar siswa}

Data minat belajar siswa diambil pada setiap siklus pada setiap pertemuan, yaitu pada siklus I pertemuan 1, 2, dan 3 dan siklus II pertemuan 1, 2, dan 3 dengan jumlah data sebanyak 35 siswa. Instrumen yang digunakan berupa lembar pengamatan yang terdiri dari empat aspek, yaitu perhatian terhadap pelajaran, mencatat materi, antusiasme mengikuti pelajaran, dan keaktifan mengikuti pelajaran. Hasil selengkapnya disajikan dalam Tabel 1. Dari Tabel 1, selanjutnya dianalisis untuk mengetahui perbandingan variabel minat siswa pada Mata Pelajaran OTKP pada siklus I pertemuan 1, 2, dan 3 dan siklus II pertemuan 1, 2, dan 3, dan hasilnya disajikan dalam bentuk diagram batang pada Gambar 1.

Tabel 1 Data minat belajar siswa pada siklus I pertemuan 1-3 dan siklus II pertemuan 1-3

\begin{tabular}{l|l|l|l|l|l|l|l|l|l}
\hline \multirow{2}{*}{ No } & \multirow{2}{*}{ Siklus penilaian minat } & \multicolumn{3}{|c|}{ Aspek yang dinilai } & \multirow{2}{*}{ Jumlah } & \multicolumn{3}{|c}{ Kriteria aktivitas } \\
\cline { 3 - 5 } \cline { 8 - 9 } & & 1 & 2 & 3 & 4 & & Tinggi & Sedang & Rendah \\
\hline 1 & Siklus I (pertemuan 1) & 20 & 25 & 15 & 6 & 66 & 2 & 13 & 20 \\
2 & Siklus I (pertermuan 2) & 22 & 20 & 25 & 10 & 77 & 5 & 14 & 16 \\
3 & Siklus I (pertemuan 3) & 25 & 12 & 30 & 20 & 87 & 12 & 13 & 10 \\
4 & Siklus II (pertemuan 1) & 27 & 10 & 35 & 24 & 96 & 15 & 14 & 6 \\
5 & Siklus II (pertemuan 2) & 30 & 8 & 38 & 30 & 106 & 20 & 14 & 1 \\
6 & Siklus II (pertemuan 3) & 30 & 6 & 40 & 38 & 110 & 24 & 11 & 0 \\
\hline
\end{tabular}

\subsection{Keaktifan Siswa dalam Diskusi}

Data keaktifan siswa dalam diskusi kelompok diambil pada siklus I pertemuan 2 dan siklus II pertemuan 1. Instrumen yang digunakan untuk pengumpulan data berupa lembar pengamat- 


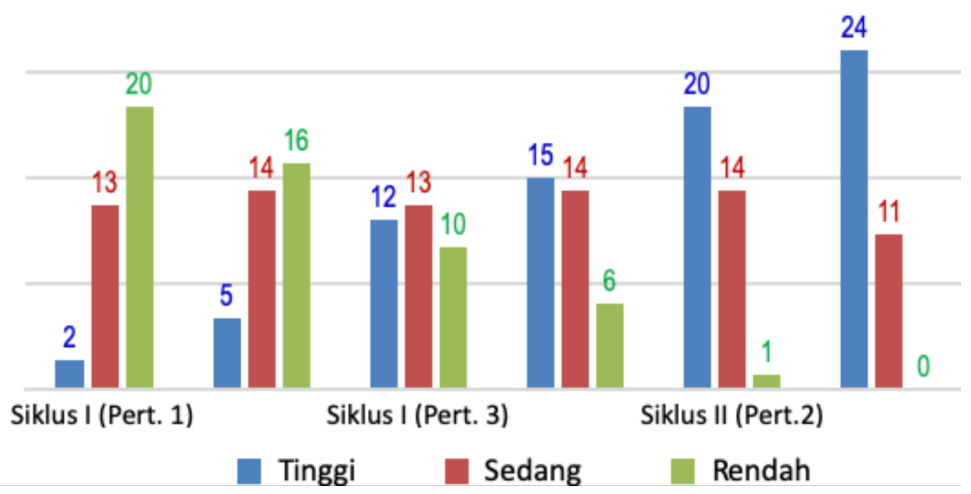

Gambar 1 Perbandingan minat belajar siswa pada siklus I pertemuan 1-3 dan siklus II pertemuan $1-3$

an yang terdiri dari 4 aspek. Hasil selengkapnya disajikan dalam Tabel 2. Hasil perbandingan variabel keaktifan siswa dalam diskusi kelompok minat siswa pada Mata Pelajaran OTKP pada siklus I pertemuan 2 dan siklus II pertemuan 1 tertampil pada Gambar 2.

Tabel 2 Data minat belajar siswa pada siklus I pertemuan 1-3 dan siklus II pertemuan 1-3

\begin{tabular}{c|c|c|c|c|l|l|l|l|l}
\hline \multirow{2}{*}{ No } & \multirow{2}{*}{ Siklus penilaian minat } & \multicolumn{3}{|c|}{ Aspek yang dinilai } & \multirow{2}{*}{ Jumlah } & \multicolumn{3}{|c}{ Kriteria aktivitas } \\
\cline { 3 - 5 } \cline { 8 - 10 } & & 1 & 2 & 3 & 4 & & Tinggi & Sedang & Rendah \\
\hline 1 & Siklus I (pertemuan 2) & 35 & 35 & 29 & 22 & 121 & 13 & 13 & 9 \\
2 & Siklus II (pertemuan 1) & 35 & 35 & 23 & 14 & 107 & 23 & 8 & 4 \\
\hline
\end{tabular}

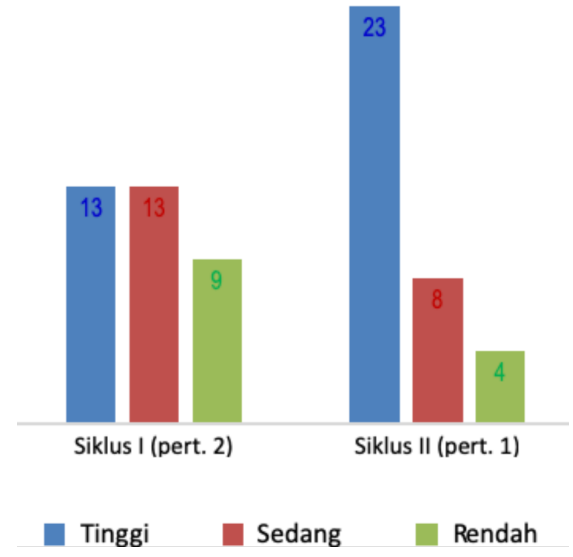

Gambar 2 Perbandingan keaktifan siswa dalam diskusi pada siklus I pertemuan 2 dan siklus II pertemuan 1

\subsection{Nilai hasil tes formatif}

Data nilai hasil tes formatif siswa diambil pada siklus I pertemuan 1 sebelum dikenalkan metode QAS dan siklus II pertemuan 1 dan 3. Instrumen tes yang digunakan adalah soal pilihan ganda dengan hanya satu jawaban benar dengan pilihan jawaban A hingga $\mathrm{E}$ ( 5 
pilihan jawaban). Hasil analisis data nilai hasil tes formatif disajikan dalam diagram batang pada Gambar 3.

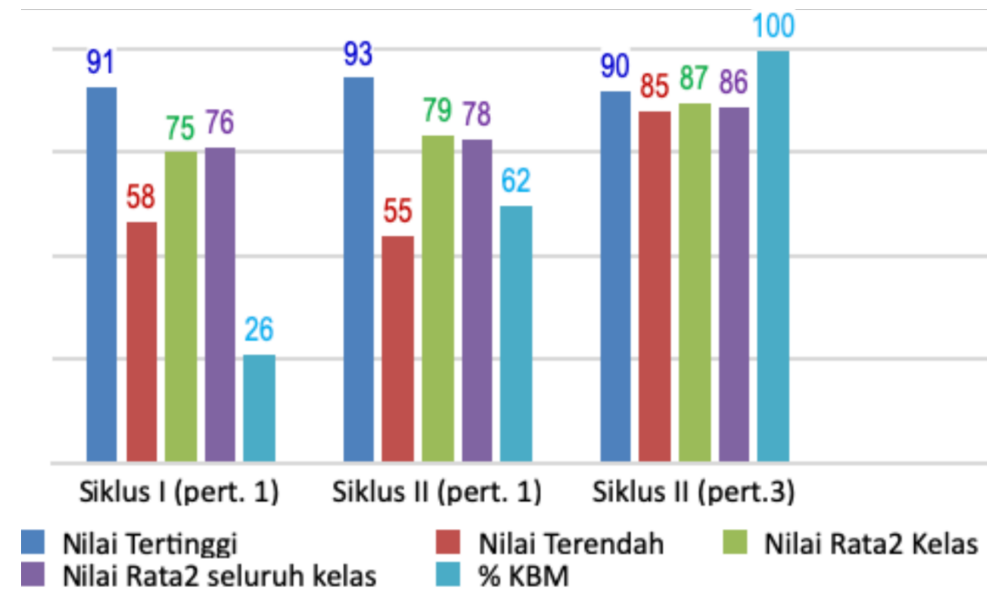

Gambar 3 Hasil Analisis Data Nilai Tes Formatif

Dari data pada Gambar 3, diperoleh data sebagai berikut:

1. siklus I pertemuan 1: nilai tertinggi 91 , nilai terendah 58 , nilai rata-rata kelas 75 , nilai rata-rata seluruh kelas 76 , dan ketuntasan belajar $26 \%$,

2. siklus II (pertemuan 1): nilai tertinggi 93, nilai terendah 55, nilai rata-rata kelas 79 , nilai rata-rata seluruh kelas 78 , dan ketuntasan belajar $62 \%$, dan

3. pada siklus II (pertemuan 3): nilai tertinggi 90, nilai terendah 85, nilai rata-rata kelas 87 , nilai rata-rata seluruh kelas 86 , dan ketuntasan belajar $100 \%$.

\subsection{Persepsi dan Kesan Siswa Terhadap Penerapan QAS}

Data persepsi dan kesan siswa terhadap penerapan metode QAS diambil setelah dilakukan perbaikan pembelajaran pada akhir Siklus II pertemuan 3. Instrumen untuk pengumpulan data berupa lembar kuesioner yang terdiri dari 15 butir pertanyaan. Hasil selengkapnya disajikan dalam diagram pie pada Gambar 4.

Berdasarkan data penelitian dan hasil analisisnya, berikut ini dikemukakan pembahasan mengenai hasil perbaikan pembelajaran melalui PTK yang dilakukan melalui penerapan metode QAS sesuai dengan hipotesis yang sudah dikemukakan sebelumnya.

Pada hipotesis tindakan pertama, diperoleh data minat belajar siswa. Dari 35 siswa sebanyak 24 siswa mempunyai minat tinggi, 11 siswa mempunyai minat sedang, dan tidak ada yang mempunyai minat rendah atau tidak berminat terhadap mata pelajaran OTKP setelah dilakukan pembelajaran dengan metode QAS.

Pada hipotesis tindakan kedua, diperoleh data keaktifan siswa dalam diskusi kelompok untuk mempelajari materi dan menyiapkan soal-soal HOTS untuk simulasi tanya jawab. Pada Siklus I pertemuan 2, dari 35 siswa terdapat 13 siswa memiliki tingkat keaktifan tinggi, 13 siswa tingkat keaktifannya sedang, dan 9 siswa lainnya memiliki tingkat keaktifan rendah. Pada siklus II pertemuan 1 tingkat keaktifan siswa dalam berdiskusi kelompok mengalami kenaikan signifikan menjadi 23 siswa yang memiliki tingkat aktifitas tinggi naik sebesar 10 siswa (77\%). Untuk tingkat keaktifan sedang terdapat 8 siswa, artinya turun sebesar 5 siswa dari 13 siswa (38\%), karena sebagian masuk kategori tinggi. Sedangkan siswa yang memiliki keaktifan rendah sebesar 4 dari 35 siswa, berarti ada penurunan sebesar $55 \%$. 


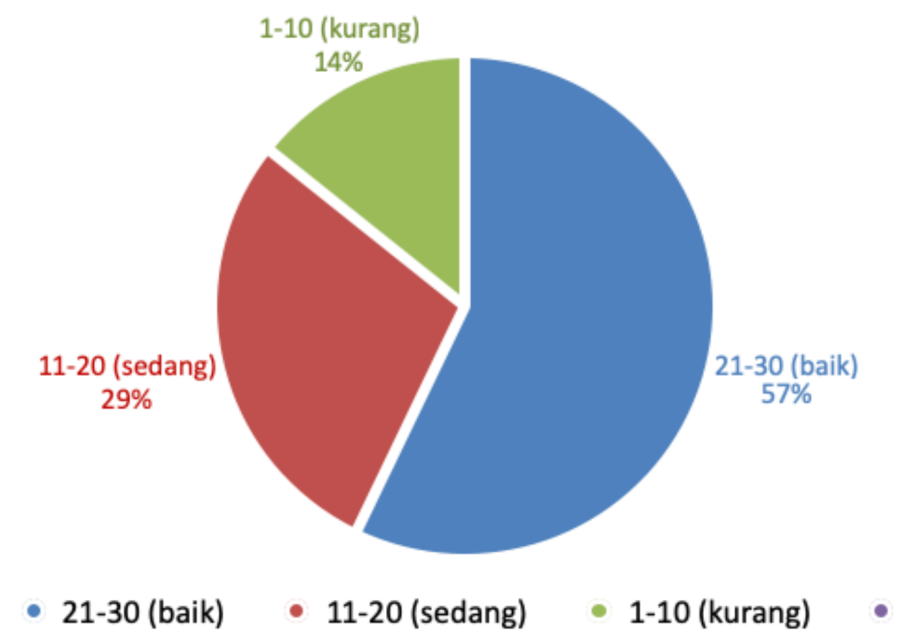

Gambar 4 Persepsi dan Kesan Siswa terhadap Metode Pembelajaran QAS

Pada hipotesis tindakan ketiga, diperoleh data nilai hasil tes formatif sebelum dan sesudah dilakukan tindakan. Sebelum dilakukan tindakan jumlah siswa yang memenuhi Ketuntasan Belajar Minimal (KBM) hanya 9 dari 35 siswa (26\%). Setelah dilakukan tindakan jumlah siswa yang memenuhi KBM menjadi 21 dari 35 siswa (62\%), dan naik lagi menjadi 35 dari $35(100 \%)$.

Pada hipotesis tindakan keempat, diperoleh data persepsi dan kesan siswa yang signifikan terhadap penerapan metode QAS. Siswa yang mempunyai kesan baik tentang pembelajaran dengan metode QAS sebesar $57 \%$ atau 20 siswa. Sedangkan siswa yang mempunyai kesan biasa saja atau sedang sebesar $29 \%$ atau 10 siswa. Selanjutnya siswa yang mempunyai kesan kurang sebesar $14 \%$ atau 5 siswa.

\section{Kesimpulan dan saran}

Berdasarkan hasil analisis data dan pembahasan hasil penelitian, dapat disimpulkan bahwa penerapan metode QAS dapat meningkatkan minat, dapat meningkatkan keaktifan siswa dalam diskusi, dan dapat meningkatkan nilai hasil tes formatif. Selain itu, ada persepsi dan kesan yang signifikan dari siswa terhadap metode pembelajaran QAS. Penerapan metode QAS menjadikan proses pembelajaran menjadi hidup, lebih menyenangkan, lebih menarik perhatian siswa, situasi kelas menjadi lebih kondusif, siswa menjadi lebih aktif, siswa memperhatikan pelajaran, dan meningkatkan profesionalisme guru.

Saran-saran yang dapat diberikan dari hasil PTK ini adalah sebagai berikut: Mengingat ada peningkatan minat belajar, keaktifan siswa, dan nilai hasil belajar, maka guru dapat menerapkan metode pembelajaran QAS pada mata pelajaran dengan karakter dan konsep yang sama. Siswa diharapkan selalu aktif dan kreatif dalam penerapan metode QAS sehingga dapat meningkatkan minat belajarnya. Mengingat pelaksanaan penelitian ini baru 2 siklus, maka peneliti lain diharapkan dapat melanjutkan untuk mendapatkan temuan yang lebih signifikan. 


\section{Ucapan Terima Kasih}

Ucapan terima kasih disampaikan Siswa Kelas OTKP SMK Negeri 2 Magelang dan Tim Narasumber Pendamping Penulisan Publikasi Ilmiah dari Universitas Muria Kudus, Universitas AMIKOM Yogyakarta, dan IST AKPRIND Yogyakarta.

\section{Pustaka}

1 M. Hafid, "Pengaruh motivasi dan kompetensi guru terhadap kinerja guru sekolah dan madrasah di lingkungan pondok pesantren salafiyah syafi'iyah sukorejo," Jurnal Pendidikan Islam Indonesia, vol. 1, no. 2, pp. 293-314, 2017.

2 E. Solihatin et al., Cooperative Learning analisis model pembelajaran IPS. Jakarta: Bumi Aksara, 2007.

3 S. E. Robert, Cooperative Learning, 2011.

4 H. A. Ahmadi and W. Supriyono, Psikologi belajar. Surakarta:Rineka Cipta, 2013.

5 N. S. Sukmadinata, Landasan psikologi proses pendidikan. Bandung: PT Remaja Rosdakarya, 2005.

6 S. Anas, Pengantar evaluasi pendidikan, 2008.

7 S. Slameto, Belajar dan faktor yang mempengaruhinya, 2015.

8 Supriyanto, Sistem Informasi Manajemen Sekolah SMKN 2 Magelang, 2018. 